\title{
Understanding Submarine Groundwater Discharge (SGD) and its Importance in the Nearshore Science is Essential? A Discussion
}

\author{
Akshai Raj ${ }^{1}$, Jeeva $C^{1}$, Shivashankar $V^{2}$, Narshimulu $G^{3}$ and Mohan PM*1 \\ ${ }^{1}$ Department of Ocean Studies and Marine Biology, Pondicherry University Off Campus, Brookshabad, Port Blair - 744112, Andaman and Nicobar Islands, \\ India \\ ${ }^{2}$ Department of Coastal Disaster Management, Pondicherry University Off Campus, Brookshabad, Port Blair - 744112, Andaman and Nicobar Islands, India \\ 3 Jawaharlal Nehru Rajkeya Mahavidyalaya, Port Blair - 744101, Andaman and Nicobar Islands, India
}

*Corresponding author: Mohan PM, Department of Ocean Studies and Marine Biology, Pondicherry, University Off Campus, Brookshabad, Port Blair - 744112, Andaman and Nicobar Islands, India.

Received Date: September 26,2020

Published Date: October 20, 2020

\begin{abstract}
Highlights
1. Existing studies suggested that there was some unexplained oceanographic process that happened in the nearshore regions.

2. Identification of some Submarine Ground Water Discharge (SGD) in and around study regions suggested that the above unexplained process may have a link with this process.
\end{abstract}

3. Suggested a combined oceanographic and hydrogeologic study essential to understand the nearshore marine environment process.

\begin{abstract}
The ground water moves into the seawater and mixes with the nearshore marine water due to its hydrological gradient is designated as a Submarine Ground Water Discharge (SGD). Reports from Hawaii west coast and Yucatan Peninsula suggested that all the freshwater entering into the sea as SGD. These flows (SGD) occur as spring and diffuse flow, through the continental shelf regions. The quantum of this mechanism was not understood properly. Similarly, the Andaman Islands also exhibit SGD since predominant volcanic out crop does not provide ample scope for the copious tropical torrential rainfall $(3394 \mathrm{~mm} / \mathrm{y})$ to perculate down and most of it divulges into the nearshore as SGD either through diffuse flow in many places or through springs in few places. The paucity of study from the area under the present investigation concerning SGD, leads to an attempt to understand the dynamics and impacts on the nearshore oceanographic process due to SGD. The existing literature also supports this factor. A submarine spring was also identified nearby island makes this concept more valid. However, an authenticated study, exclusively need for combination of groundwater and nearshore parameters may really reveal the factors, what's is exactly happening in the nearshore environment, which may reverse the paradigm of nearshore eco-biological inferences.
\end{abstract}

Keywords: Submarine groundwater discharge; SGD; Islands; Andaman; India

\section{Introduction}

The ground water, due to its hydrological gradient moves into the seawater and mixing thereupon, designated as a Submarine Ground Water Discharge (SGD). Chruch [1] defined SGD as the direct outflow of groundwater through the ocean-land interface. This flow includes both groundwater and re-circulated portion of the salty groundwater. The SGD study has emerged as a hot research topic in the groundwater since last decade. This study may also cover the freshwater discharge through the ground, the recycled seawater and brackish water intrusion in the seawater. Church [1] and Moore [2] reported that the volume of SGD in the coastal oceans are almost comparable to river discharge, in their study locations. Kay et al., [3] and Hanshaw \& Back [4], reported that, respectively, West coast of Hawaii and part of the Yucatan Peninsula exhibited almost all 
the freshwater enter into the ocean as SGD. Also, a volcanic island with a sandy coast discharge in the South Sea of Korea discharged freshwater at a rate of $50-300 \mathrm{~m} / \mathrm{y}$, which is higher than the continental coast region [5]. Since SGD occurs as spring and diffuse flow in continental shelf regions, the magnitude and mechanism are also poorly understood. The Andaman Islands with the poorly developed stream network system, unyielding acquifers and torrential rainfall $(3394 \mathrm{~mm} / \mathrm{y})$ may infiltrate through the fissures, cracks, and crevices of impervious subsurface volcanic rock. Since, the focus area is devoid of primary porosity to ground water and provide SGD as a spring in a few places and diffuse flow in majority of the areas of nearshore waters. The present study tries to evaluate whether any submarine ground water flow existed in this island environment through indirect shreds of evidences as well.

\section{Materials and Methods}

The present SGD evaluation was carried out through the different existing nearshore studies which was provided an unexplained variation of physical-chemical parameters and authors personal observations of freshwater inflow into the sea, in the study area of the Andaman Islands (Figure 1).

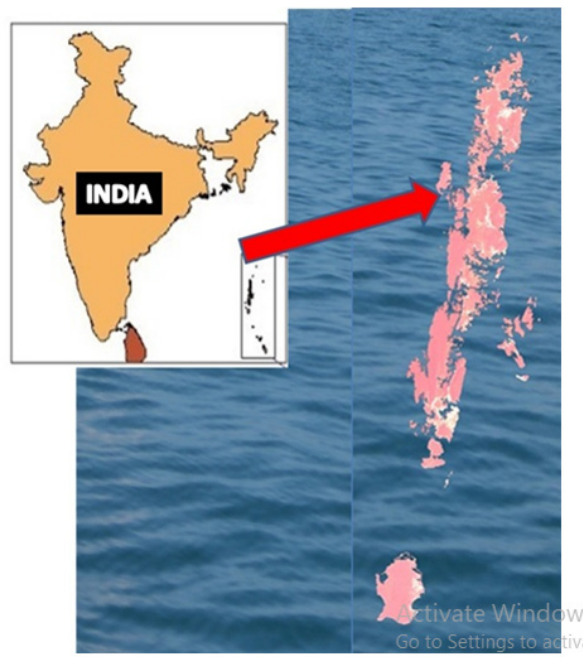

Figure 1: Study Area - Andaman Islands.

\section{Results and Discussion}

Case 1: The studies of Kumari et al., [6] suggested in the Nicobar Group of Islands showed a distinct increment or decrement of Dissolved Organic Carbon (DOC) and Dissolved Inorganic Carbon (DIC) with reference to depth i.e. surface to $50 \mathrm{~m}$ (Figure 2A, 2B, 3A
3B). Similarly, the salinity also exhibited a slight reduction in these depths (Figure 4A, 4B). These variations were not able to provide much explanation for the chemistry of the existing ocean waters. However, when incorporating the SGD concept, these variations may be inferred well than the existing explanations.

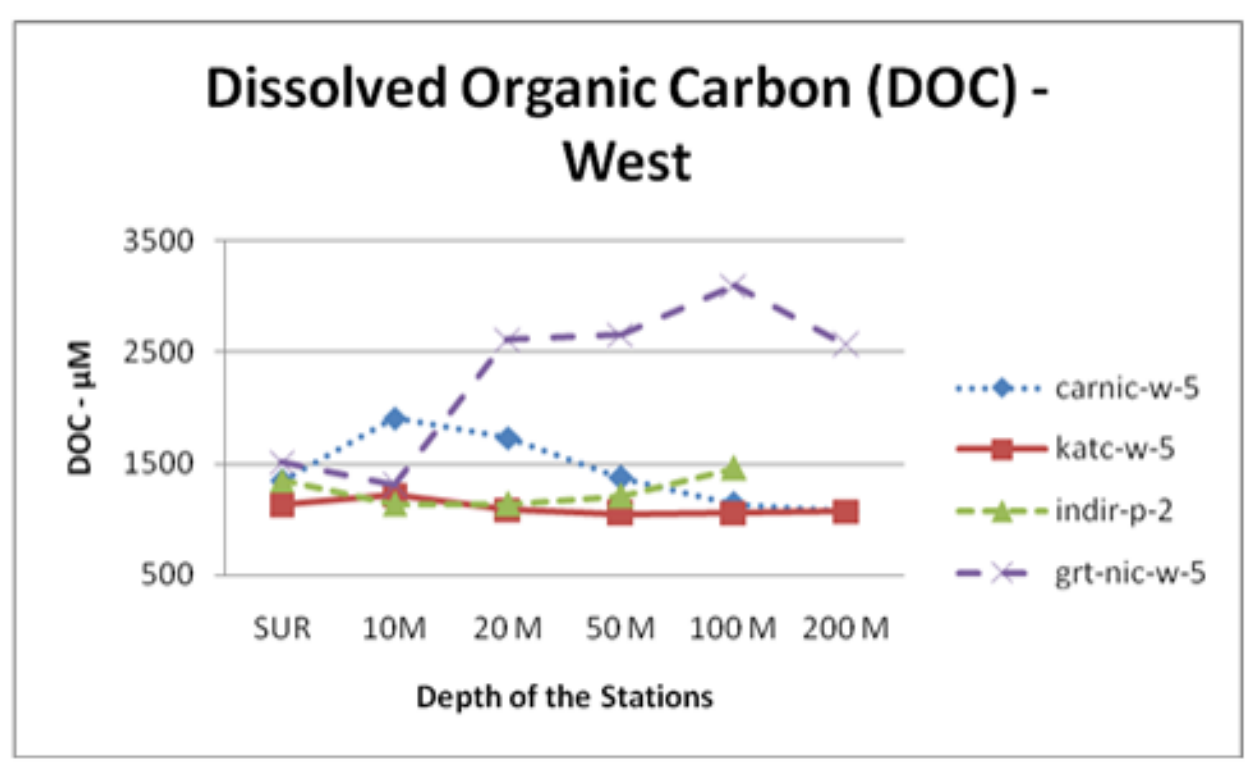

Figure 2A: Distribution of dissolved organic carbon (DOC) - Western side - carnic - Car Nicobar; katc- Katchall; indira - Indira Point; grt-nicGreat Nicobar. 


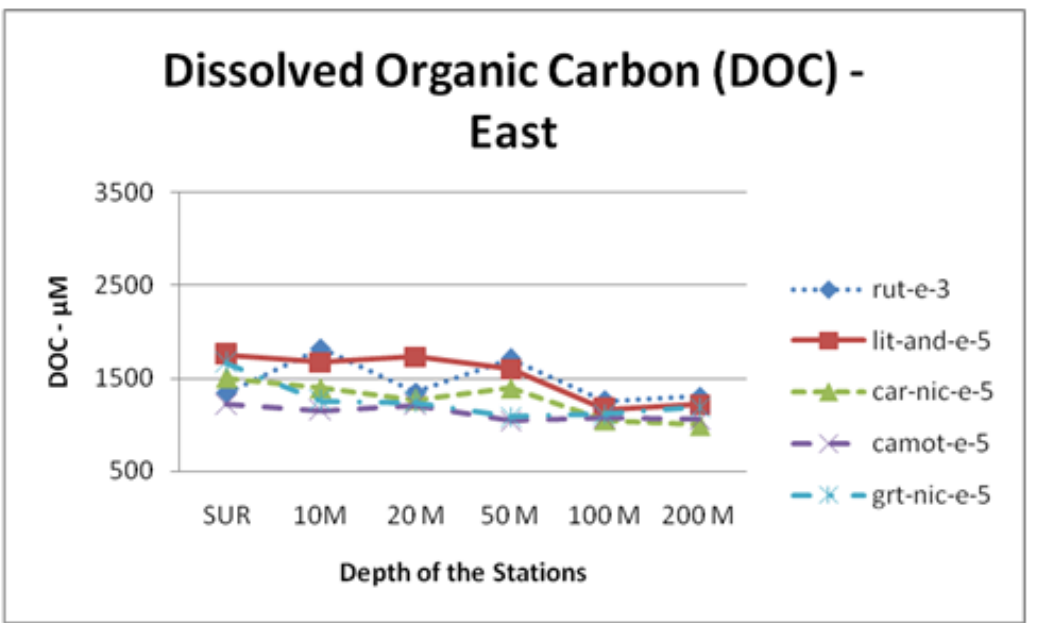

Figure 2B: Distribution of dissolved organic carbon (DOC) - Eastern side - rut- Rutland; lit-and-Little Andaman; car-nic - Car Nicobar; camotCamorta; grt-nic-Great Nicobar.

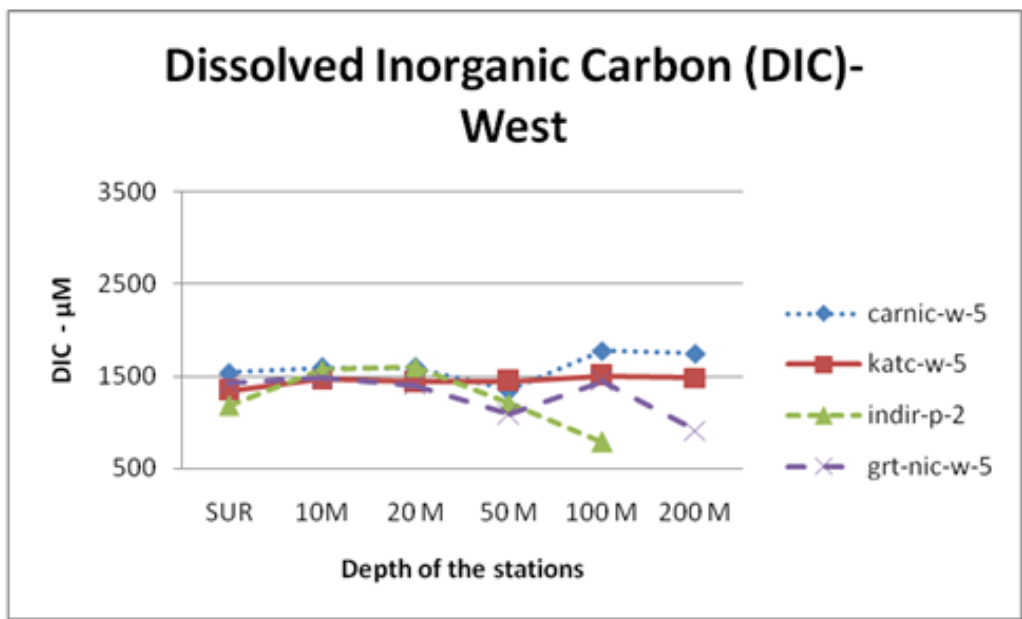

Figure 3A: Distribution of dissolved inorganic carbon (DIC) - Western side - carnic - Car Nicobar; katc- Katchall; indir - Indira Point; grt-nicGreat Nicobar.

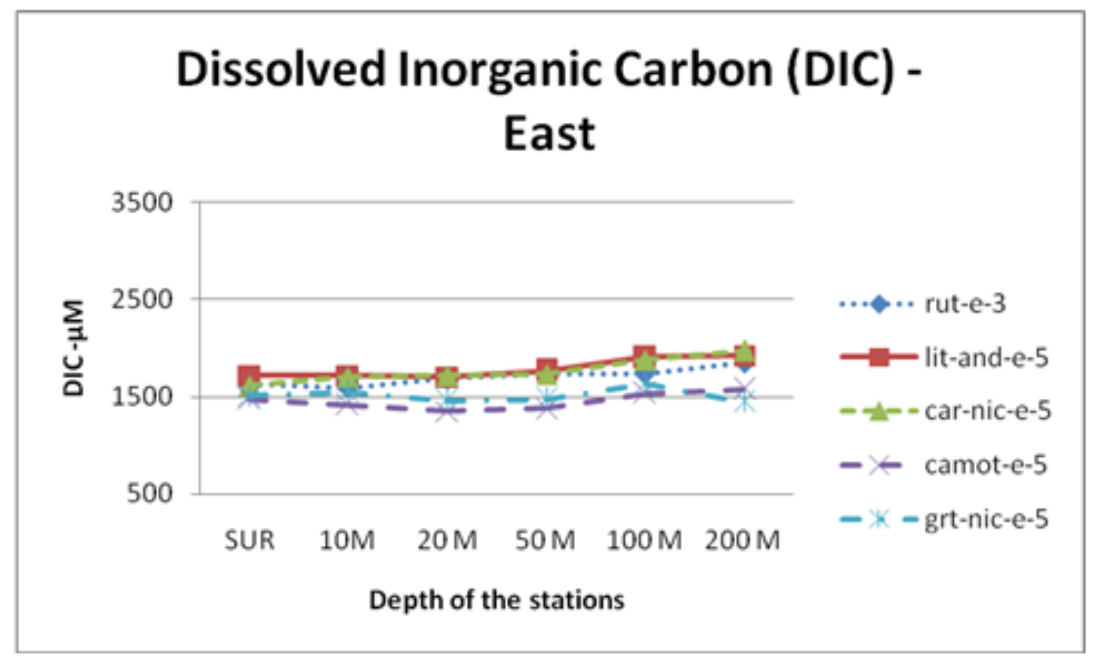

Figure 3B: Distribution of dissolved inorganic carbon (DIC) - Eastern side - rut- Rutland; lit-and-Little Andaman; car-nic - Car Nicobar; camotCamorta; grt-nic-Great Nicobar. 


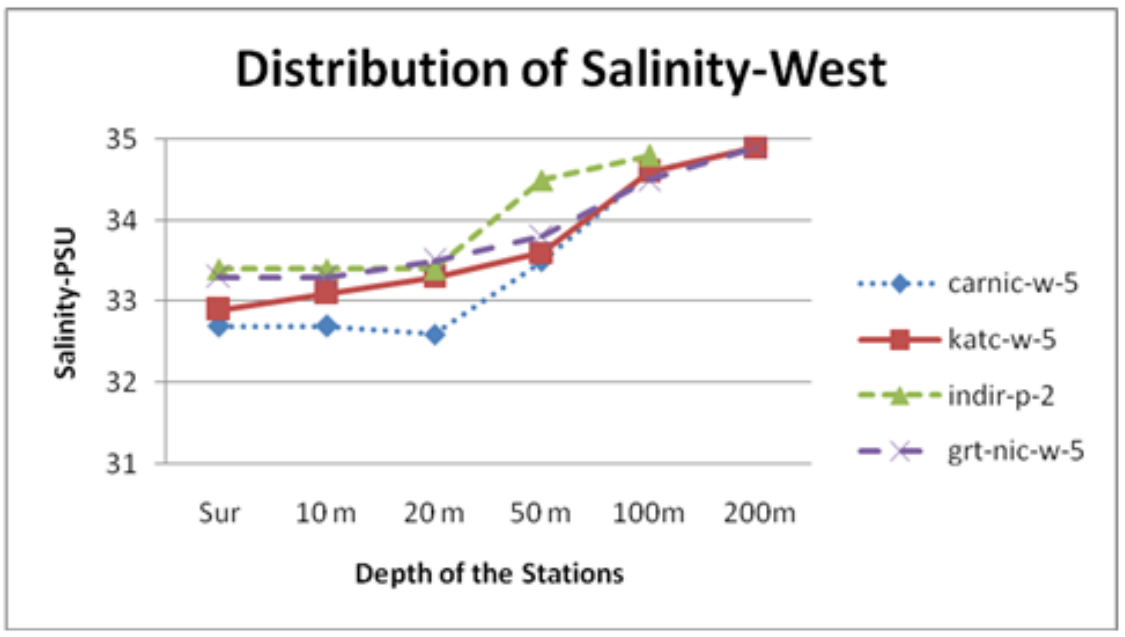

Figure 4A: Distribution of Salinity - Western side - carnic - Car Nicobar; katc- Katchall; indir - Indira Point; grt-nic-Great Nicobar.

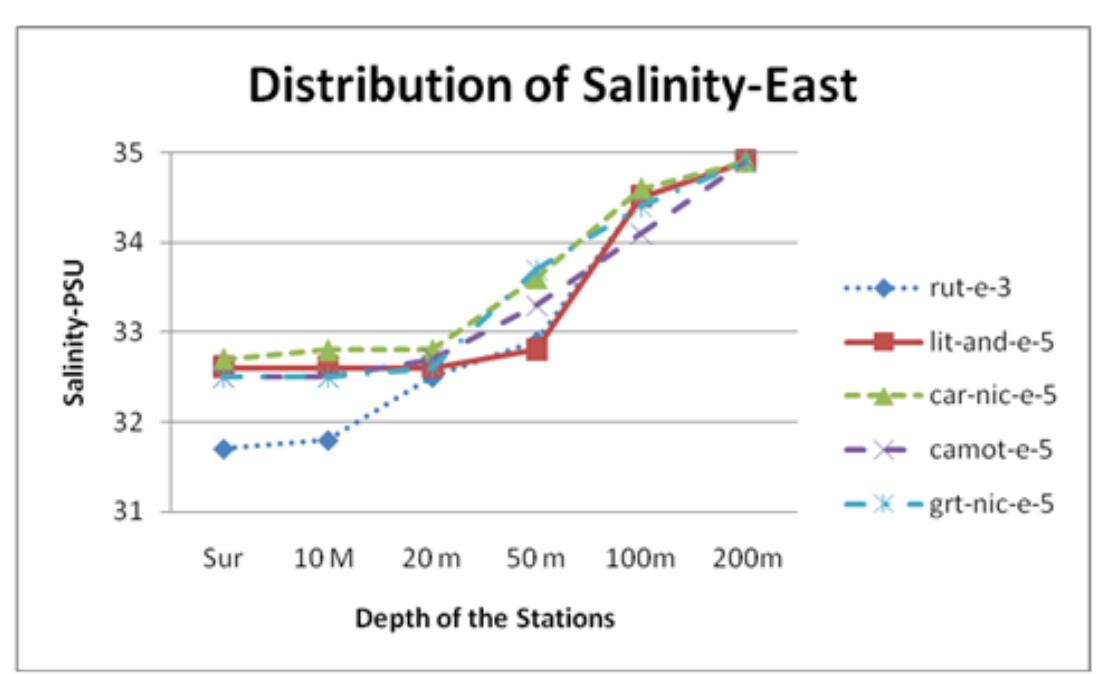

Figure 4B: Distribution of Salinity - Eastern side - rut- Rutland; lit-and-Little Andaman; car-nic - Car Nicobar; camot- Camorta; grt-nic-Great Nicobar.

Case 2: Mohan et al., [7] studied the nearshore waters off Port Blair and found the significant variation of DOC and DIC concentration within the depth of surface to $15 \mathrm{~m}$ water depth. Especially, when the analysis of DOC data revealed that between $5 \mathrm{~m}$ and $10 \mathrm{~m}$ depth, a sudden increase of DOC observed in all the three studied stations (Table 1A, 1B, 1C). The variation was around $20 \mu \mathrm{M}$ between the studied upper and bottom water column. Similarly, the DIC concentration also referred, it also showed a significant similar level of variation in these water columns. This sudden variation in the mid-depth was not able to explain the normal chemical processes which are known for the oceanographic process. Here, if one can assume that the SGD may have exercised its influence in these stations depth, this process was better explained.

Table 1A: Distribution of Temperature, pH, Salinity, Dissolved Organic Carbon (DOC) and Dissolved Inorganic Carbon (DIC) - (8 nos) off Chatham Island.

\begin{tabular}{|c|c|c|c|c|}
\hline \multicolumn{5}{|c|}{ Chatham } \\
\hline Average & Surface & $5 \mathrm{~m}$ & $10 \mathrm{~m}$ & $15 \mathrm{~m}$ \\
\hline Temperature ${ }^{\circ} \mathrm{C}$ & 29.33 & 29.06 & 28.87 & 28.52 \\
\hline Minimum & 28.73 & 28.35 & 28.06 & 28.75 \\
\hline $\mathrm{Ph}$ & 8.43 & 8.38 & 8.38 & 8.4 \\
\hline Salinity & 34.01 & 34.91 & 35.17 & 35.19 \\
\hline Maximum & 35.4 & 34.47 & 36.07 & 36.15 \\
\hline
\end{tabular}




\begin{tabular}{|c|c|c|c|c|}
\hline DOC $\mu \mathrm{M} / \mathrm{L}$ & 86.59 & 106.19 & 103.01 & 93.75 \\
\hline Minimum & 56 & 43 & 39 & 125.44 \\
\hline DIC $\mu \mathrm{M} / \mathrm{L}$ & 121.5 & 138.19 & 333 & 392 \\
\hline Maximum & 283 & 378 & 125.19 \\
\hline
\end{tabular}

Table 1B: Distribution of Temperature, pH, Salinity, Dissolved Organic Carbon (DOC) and Dissolved Inorganic Carbon (DIC) - (8 nos) off North Bay Island.

\begin{tabular}{|c|c|c|c|c|}
\hline \multicolumn{5}{|c|}{ North Bay } \\
\hline Average & Surface & $5 \mathrm{~m}$ & $10 \mathrm{~m}$ & $15 \mathrm{~m}$ \\
\hline Temperature ${ }^{\circ} \mathrm{C}$ & 29.25 & 28.88 & 28.75 & 28.68 \\
\hline Minimum & 30.22 & 29.5 & 29.51 & 29.51 \\
\hline $\mathrm{Ph}$ & 8.35 & 8.37 & 8.34 & 8.32 \\
\hline Salinity & 34.87 & 35.19 & 35.25 & 35.23 \\
\hline $\mathrm{DOC} \mu \mathrm{M} / \mathrm{L}$ & 72.19 & 93.94 & 106.31 & 80.25 \\
\hline Maximum & 136 & 149 & 179 & 109 \\
\hline $\mathrm{DIC} \mu \mathrm{M} / \mathrm{L}$ & 135.06 & 133.06 & 102.81 & 130.31 \\
\hline Maximum & 367 & 393 & 171 & 370 \\
\hline
\end{tabular}

Table 1C: Distribution of Temperature, pH, Salinity, Dissolved Organic Carbon (DOC) and Dissolved Inorganic Carbon (DIC) - (8 nos) in off Carbyns Cove Island.

\begin{tabular}{|c|c|c|c|c|}
\hline \multicolumn{5}{|c|}{ Carbyns Cove } \\
\hline Average & Surface & $5 \mathrm{~m}$ & $10 \mathrm{~m}$ & $15 \mathrm{~m}$ \\
\hline Temperature ${ }^{\circ} \mathrm{C}$ & 28.86 & 28.85 & 28.77 & 28.72 \\
\hline Minimum & 28.19 & 28.17 & 28.17 & 28.18 \\
\hline $\mathrm{Ph}$ & 8.28 & 8.28 & 8.28 & 8.33 \\
\hline Minimum & 7.98 & 8.06 & 8.1 & 8.1 \\
\hline Salinity & 35.13 & 35.23 & 35.31 & 35.36 \\
\hline Minimum & 34.14 & 34.43 & 34.72 & 34.71 \\
\hline $\mathrm{DOC} \mu \mathrm{M} / \mathrm{L}$ & 71.06 & 102.69 & 92.94 & 71.13 \\
\hline Minimum & 14 & 21 & 52 & 21 \\
\hline $\mathrm{DIC} \mu \mathrm{M} / \mathrm{L}$ & 122.81 & 122.81 & 128.81 & 127.63 \\
\hline Maximum & 348 & 307 & 292 & 303 \\
\hline
\end{tabular}

Case 3: Mohan et al., [8] conducted an experimental study in the laboratory conditions to mimic the similar kind of environment existed in the nearshore region articulated that the variation happened in the water column concerning DOC and DIC do not depict similar results to the naturally observed variations in the different water column. An insitu systematic reduction or increment took place in the existing water column. This study also supports that in the nearshore waters, other than the oceanographic process some other factor influenced this variation.

Case 4: Mohan \& Kumari [9] studied four months of daily variation of temperature, salinity and $\mathrm{pH}$ in the nearshore waters of the Carbyns Cove beach (Table 2) suggested that there was an increment of salinity from 30.0 to 34.5 , but the $\mathrm{pH}$ which was not showing any such an increment during this period (7.5 to 8.0). This variation was mainly observed during the period of non-rainy season, i.e. December to April. This was also suspected for SGD influences in this region, because the normal process of marine environment, freshwater input through rivers may provide an increment of elemental concentration and decrement of $\mathrm{pH}$.

Case 5: Kumari \& Mohan [10] studied in another two islands continuously three-year period for the temperature, salinity, and $\mathrm{pH}$ parameters of the waters (Table 3). This study showed very interesting fact that the water temperature comparatively higher in the bottom water $(10 \mathrm{~m})$ temperature than the surface temperature, in certain periods. Further, it is also observed during non-rainy season period, the surface temperature value will be similar to next month bottom water temperature, i.e., the surface temperature in the month of April is $31.71^{\circ} \mathrm{C}$, the May month bottom water $(10 \mathrm{~m})$ depth temperature is $31.61^{\circ} \mathrm{C}$ in the same station. Further, during this studied period, the increment of salinity and $\mathrm{pH}$ also observed a significant increment, i.e., 1.32 to 1.51 and 0.41 units of $\mathrm{pH}$. The interesting fact to be noticed in this study period is low rainfall and an increment of temperature was evidenced in the atmosphere. This increment of temperature at a depth of $10 \mathrm{~m}$, equivalent to surface water may be inferred with the influence of SGD impact. 
Table 2: The Maxima and Minima Values of Temperature, Salinity and pH of Study Period.

\begin{tabular}{|c|c|c|c|c|}
\hline \multicolumn{5}{|c|}{ Carbyns Cove } \\
\hline Average & 13-Dec & January -14 & 14-Feb & March -14 \\
\hline Temperature ${ }^{\circ} \mathrm{C}$ & $27.00-31.50$ & $25.00-30.00$ & $26.00-32.50$ & $29.00-32.00$ \\
\hline Salinity & $31.00-32.00$ & $30.00-34.50$ & $30.50-33.00$ & $32.00-34.50$ \\
\hline $\mathrm{Ph}$ & $07.50-08.00$ & $07.50-08.00$ & $07.50-08.00$ & $07.50-08.00$ \\
\hline
\end{tabular}

Table 3: Average temperature, $\mathrm{pH}$ and salinity recorded in Joyy Buoy and Redskin Islands during the years 2009,2010 and 2011.

\begin{tabular}{|c|c|c|c|c|c|c|}
\hline \multicolumn{7}{|c|}{ Jolly Buoy Island - Temperature ${ }^{\circ} \mathrm{C}$} \\
\hline Transect & \multicolumn{3}{|c|}{ Surface Average } & \multicolumn{3}{c|}{$10 \mathrm{~m}$-Average } \\
\hline & 2009 & 2010 & 2011 & 2009 & 2010 & 2011 \\
\hline T1 & 28.77 & 29.37 & 28.68 & 28.83 & 29.29 & 29.32 \\
\hline T2 & 28.63 & 29.41 & 28.62 & 28.83 & 28.59 \\
\hline T3 & 28.85 & 29.45 & 28.71 & 28.8 & 29.32 & 29.38 \\
\hline T4 & 28.98 & 29.65 & 28.75 & 28.9 & 28.65 \\
\hline T1 & 29.04 & 29.72 & 28.97 & 29.14 & 29.38 & 28.71 \\
\hline T2 & 29.09 & 29.64 & 28.92 & 29.08 & 29.39 & 28.76 \\
\hline T3 & 29.08 & 29.45 & 28.77 & 29.11 & 29.43 & 28.7 \\
\hline
\end{tabular}

\begin{tabular}{|c|c|c|c|c|c|c|}
\hline \multicolumn{7}{|c|}{ Jolly Buoy Island - pH } \\
\hline \multirow[t]{2}{*}{ Transect } & \multicolumn{3}{|c|}{ Surface Average } & \multicolumn{3}{|c|}{ 10m-Average } \\
\hline & 2009 & 2010 & 2011 & 2009 & 2010 & 2011 \\
\hline $\mathrm{T} 1$ & 7.52 & 7.98 & 7.95 & 7.54 & 8.02 & 7.91 \\
\hline $\mathrm{T} 2$ & 7.48 & 8.02 & 7.98 & 7.5 & 8.07 & 7.95 \\
\hline T3 & 7.51 & 8.02 & 7.94 & 7.56 & 8.15 & 8.04 \\
\hline $\mathrm{T} 4$ & 7.52 & 7.93 & 7.85 & 7.52 & 7.95 & 7.87 \\
\hline \multicolumn{7}{|c|}{ Redskin Island - pH } \\
\hline $\mathrm{T} 1$ & 7.64 & 7.84 & 7.8 & 7.6 & 7.94 & 7.89 \\
\hline $\mathrm{T} 2$ & 7.51 & 7.82 & 7.69 & 7.51 & 7.82 & 7.89 \\
\hline T3 & 7.51 & 7.79 & 7.7 & 7.48 & 7.86 & 7.71 \\
\hline
\end{tabular}

\begin{tabular}{|c|c|c|c|c|c|c|}
\hline \multicolumn{7}{|c|}{ Jolly Buoy Island - Salinity } \\
\hline Transect & \multicolumn{3}{|c|}{ Surface Average } & \multicolumn{3}{c|}{$10 \mathrm{~m}$-Average } \\
\hline & 2009 & 2010 & 2011 & 2009 & 2010 & 2011 \\
\hline T1 & 31.23 & 31.33 & 32.68 & 31.18 & 31.4 & 32.66 \\
\hline T2 & 31.18 & 31.31 & 32.69 & 31.17 & 31.42 & 32.69 \\
\hline T3 & 31.16 & 31.39 & 32.72 & 31.16 & 31.48 & 32.74 \\
\hline T4 & 31.24 & 31.37 & 32.67 & 31.19 & 31.37 & 32.67 \\
\hline T1 & 30.98 & 31.38 & 32.59 & 31.12 & 31.4 & 32.66 \\
\hline T2 & 31.08 & 31.38 & 32.53 & 31.32 & 31.42 & 32.56 \\
\hline T3 & 31.2 & 31.4 & 32.55 & 31.21 & 31.48 & 32.5 \\
\hline
\end{tabular}

Case 6: Mohan et al., [11] reported that 2010 and 2015 coral reef bleaching was taken place in the Islands of Andaman suggested that in the year 2010, the bleaching was taken only LWM to $5 \mathrm{~m}$ depth regions and in the year 2015, the bleaching was taken only by the wavy pattern and also less than $5 \mathrm{~m}$ depth (Figures 5-9). The factor also suggested the increment in temperature of water column taken place only in the top $5 \mathrm{~m}$ depth and corals were bleached. In the year 2015, a wavy selective bleaching observed in these locations also inferred better, if the influence of SGD may be considered, instead of the climatic variable influences for this process. 


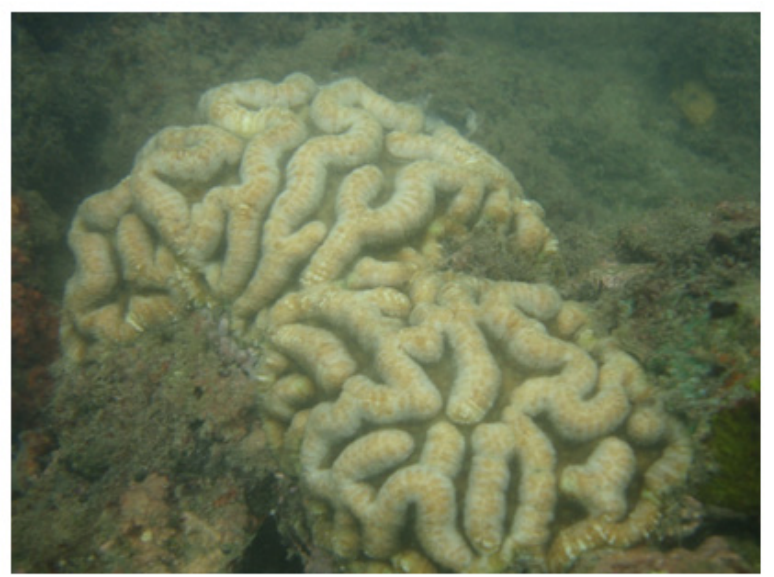

Figure 5: Non bleaching coral.

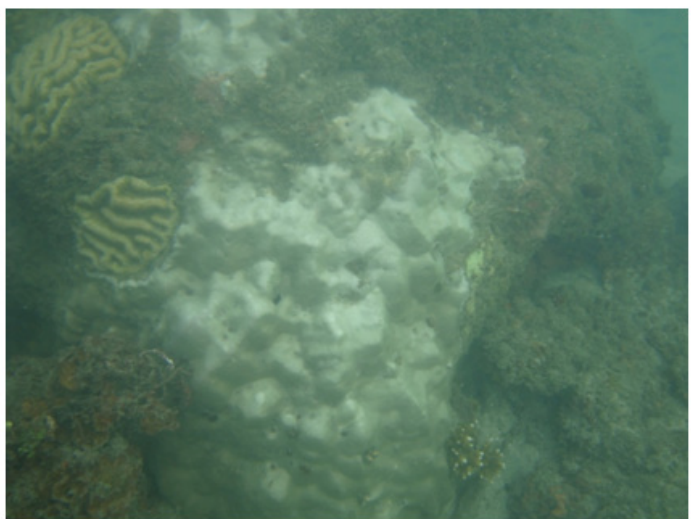

Figure 6: Bleaching coral adjunct with bleaching coral at the same depth.

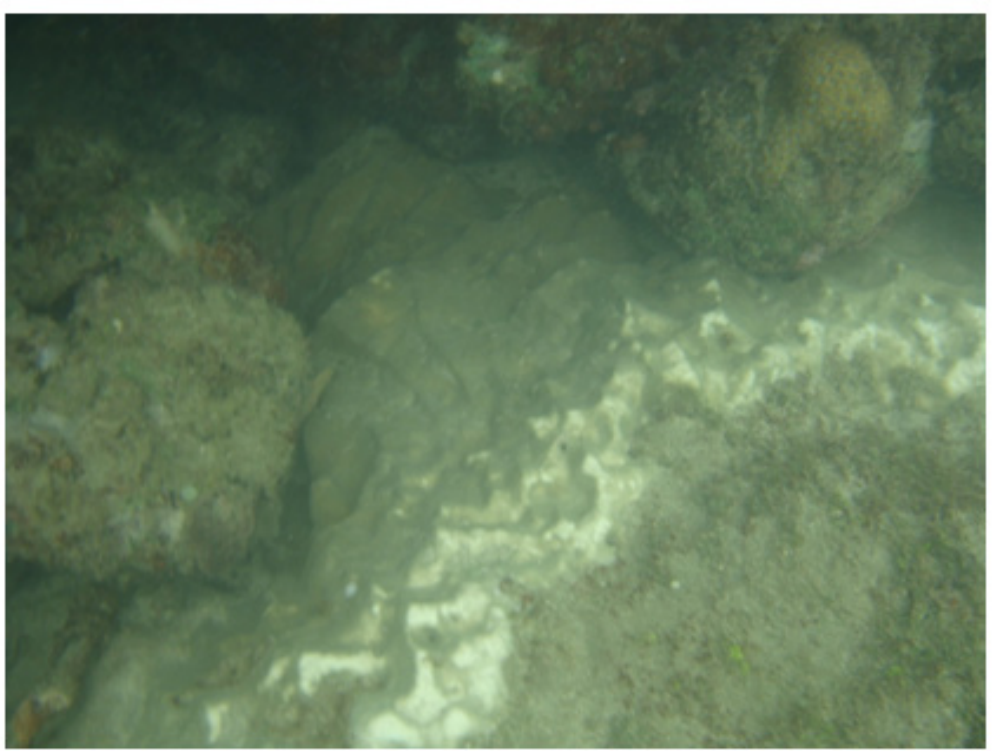

Figure 7: Bleaching effected in wavy pattern in a solid coral block. 


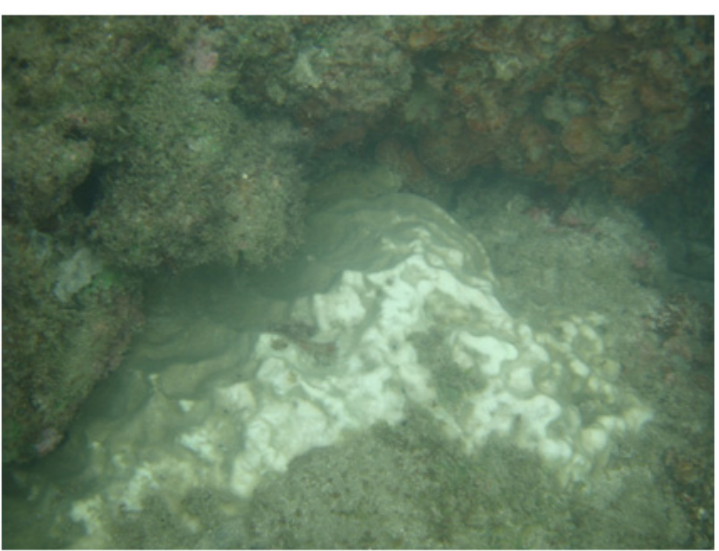

Figure 8: Bleaching effected in wavy pattern in a solid coral block.

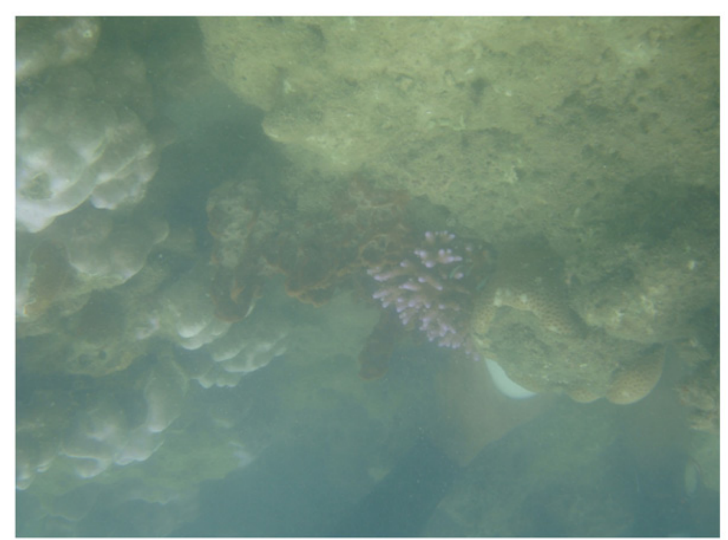

Figure 9: Bleaching and Non bleaching corals existed side by side.

Case 7: Kumari [12] suggested that there is a clear cut reduction of salinity from the studied years 2014 to 2016, around a unit, invariably concerning an increment of temperature (Table 4), in the water column of $15 \mathrm{~m}$ depth (Figures 10,11,14). This variance not only found it off the Port Blair coast. Almost $300 \mathrm{~km}$ distance, far away northern part of these islands also observed the same trend (Figures 12,13). These findings were considered as a non-existing oceanographic process elsewhere discussed. However, considered it is the influence of SGD, then this finding will be clearly explained.

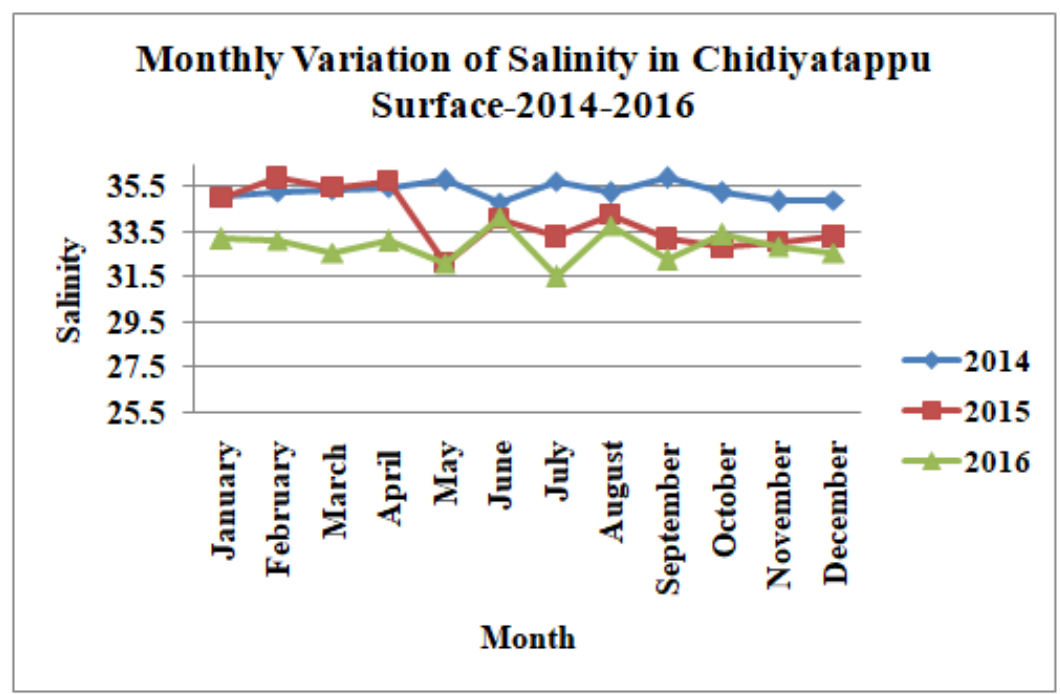

Figure 10: Surface - 2014 - 34.78-35.86 (1.08); 2015 - 32.12-35.86 (3.74); 2016 - 31.52-34.18 (2.66). 


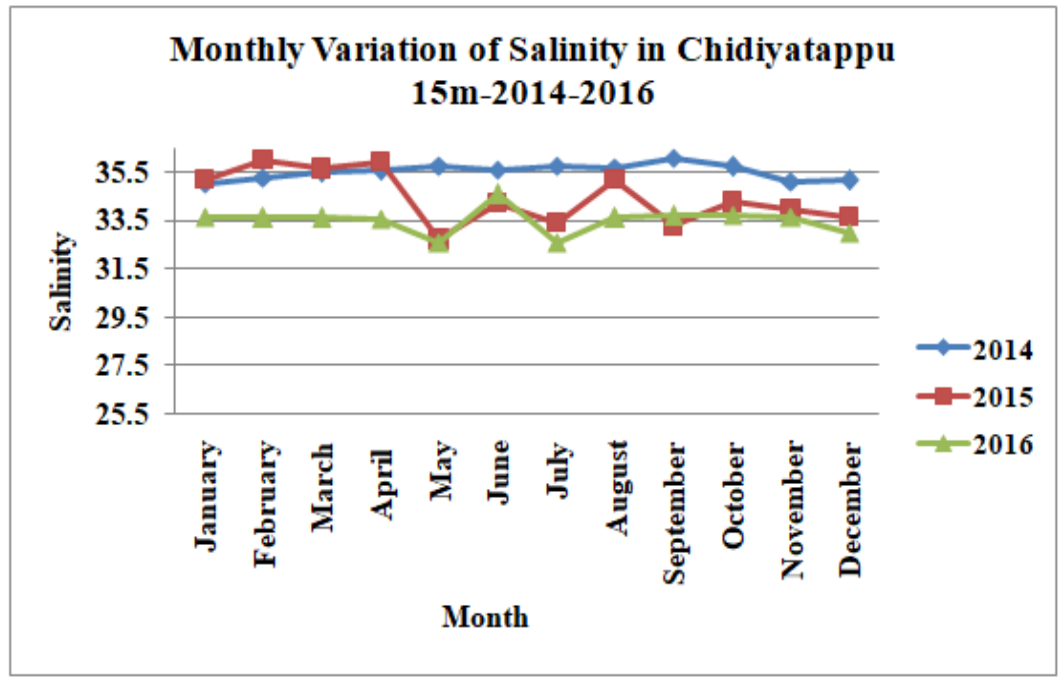

Figure 11: 15m depth - 2014 - 35.01-36.06 (1.05); 2015 - 32.71-36.00 (3.29); 2016 - 32.56-34.56 (2.00).

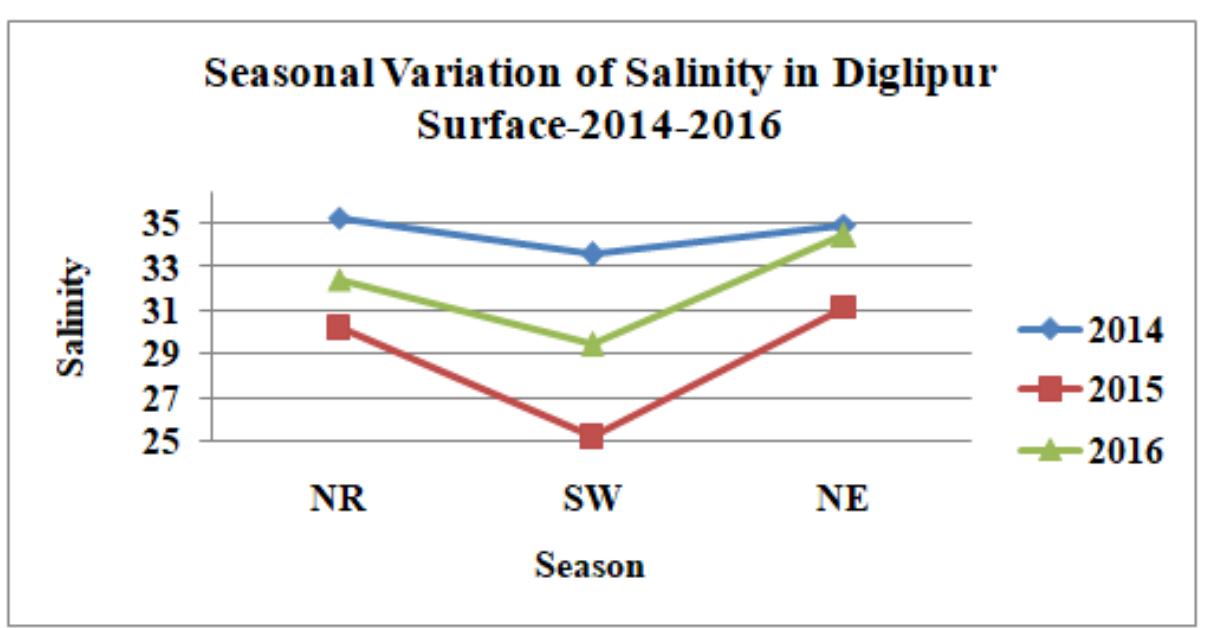

Figure 12: Surface - 2014 - 33-58-35.24 (1.66); 2015 - 25.23-31.12 (5.89); 2016 - 29.47-34.45 (4.98).

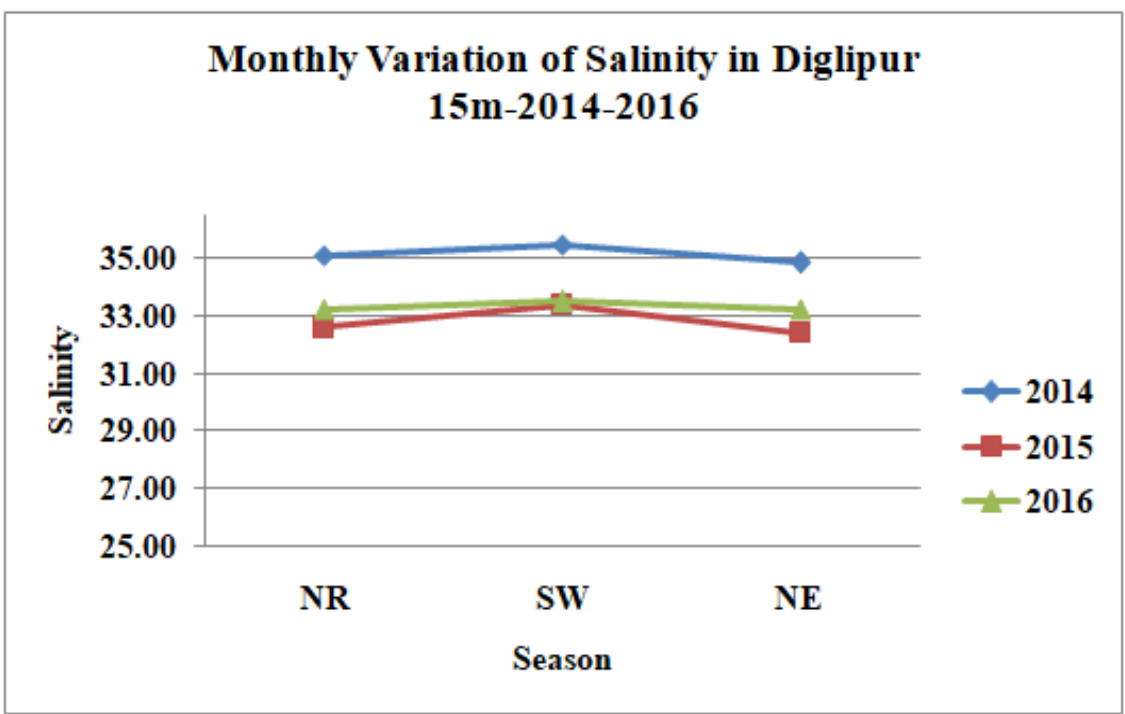

Figure 13: 15m depth - 2014 - 34.81-35.42 (0.61); 2015 - 32.42-33.38 (0.96); 2016 - 33.23-33.47 (0.24). 


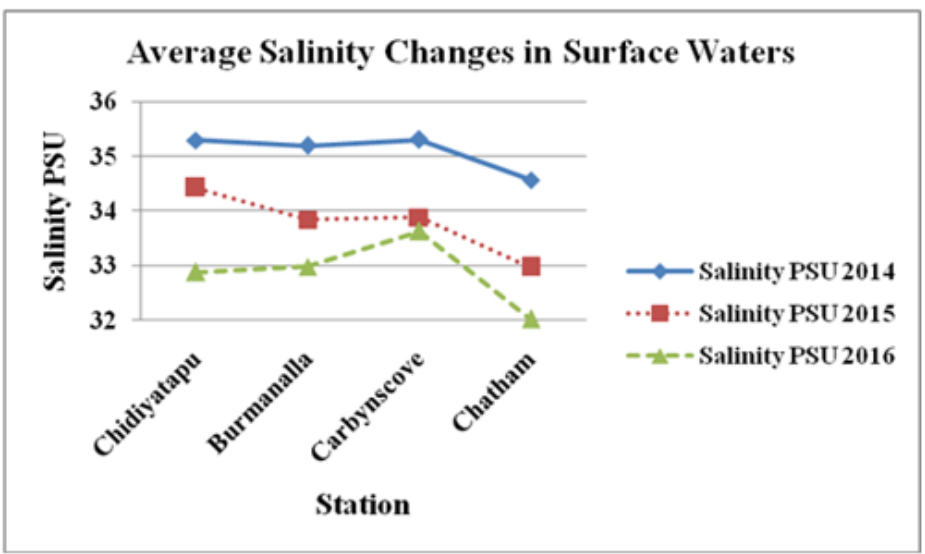

Figure 14: Change of Salinity off Port Blair Coast.

Table 4: The monthly rainfall data for the year 2013, 2014, 2015 and 2016 for Andaman Islands.

\begin{tabular}{|c|c|c|c|c|c|}
\hline S.NO & Month & $\mathbf{2 0 1 3}$ & $\mathbf{2 0 1 4}$ & $\mathbf{2 0 1 5}$ & $\mathbf{2 0 1 6}$ \\
\hline 1 & January & 28.9 & 0.4 & 0 & 0 \\
\hline 2 & February & 0.1 & 0 & 8 & 0 \\
\hline 3 & March & 5.7 & 0 & 149.1 & 7 \\
\hline 4 & April & 21.3 & 0 & 364 & 342.7 \\
\hline 5 & May & 659.1 & 501.7 & 407.5 & 491 \\
\hline 6 & June & 615.6 & 696.6 & 292.4 & 421.1 \\
\hline 7 & July & 597.1 & 283.5 & 557.3 & 332.7 \\
\hline 8 & August & 235.2 & 409.4 & 419 & 991.2 \\
\hline 9 & September & 493.2 & 564.9 & 225 & 302 \\
\hline 10 & October & 267.1 & 174.6 & 205.8 & 168.2 \\
\hline 12 & November & 352.7 & 16 & 136.6 & 493.8 \\
\hline Total & December & 129.4 & 2877 & 2887.9 & 3650.1 \\
\hline
\end{tabular}

\section{Existing Literatures}

Johannes \& Hearn [13], Lapointe \& O’Connell [14], Slomp \& Van Cappellen [15] and Luo et al. [16] reported that the nutrient rich, fresh water entered into the coastal ecosystem through SGD. Similarly, the reports of Burnett et al. [17], Moore [18] and Moosdorf et al. [19] suggested that the SGD is entering into the coastal waters universally. Taniguchi et al. [20] reported that almost $10 \%$ of the gross river runoff enters into the ocean as SGD. Dale \& Miller [21], Waska \& Kim [22], Encarnação et al. [23], Hata et al. [24], Amato et al. [25], Utsunomiya et al. [26], Lecher \& Mackey [27], Piló et al. [28] and Foley [29] reported that the benthic community habitat modification may happen due to the influence of SGD which in turn increment of primary and secondary producer biomass. Lilkendey et al. [30] reported in the tide pool waters exhibited that the pure marine waters have a salinity of 35 PSU and fresh SGD influenced tide pool showed only 20 PSU during the four-month study.

\section{SGD Study in the Present Studied Environment}

One of the Island near Port Blair called Rutland Island, opposite to Chidiyatappu, which has a location called Chain Nalah, where a submarine spring (Figures 15-17) was identified in the intertidal zone. This spring flow rate during Non-rainy season (April 2019) was $6.14 \mathrm{ml} / \mathrm{Sec}$. A day the water flow was identified $230.50 \mathrm{~L} /$ day. So, the calculations showed that per year the flow was1.9 Lakh L/year. This water has a salinity of 0 PSU and pH is 11.094 , i.e., highly alkaline nature. The studied period temperature is $24.5^{\circ} \mathrm{C}$. Port Blair coast, near eastern side, close to the Coast Guard Jetty, the location $\left(11^{\circ} 39^{\prime} 19.05 \mathrm{~N}-092^{\circ} 43^{\prime} 14.30 \mathrm{E}\right)$ is a steep clip of an alluvial soil, with a height of approximately $20 \mathrm{~m}$ from the MSL (Figure 18). Entry into this part is restricted area due to the Coast Guard Jetty presence. During the low tide period, below the MSL, the flow of freshwater was observed through the mudstone and alluvial contact (Figure19). Three locations, within 50m distance (Figures 20-22). The water status is good with a flow rate of $5 \mathrm{ml} /$ sec. It has been estimated around $432 \mathrm{~L} /$ day and in the year it may around 1,55,520 L/year at a point. The length of the seepage may be around $4 \mathrm{~m}$ horizontal distance. The Salinity is 0.230 with a $\mathrm{pH}$ of 10.084 and the temperature is $22.5^{\circ} \mathrm{C}$. 


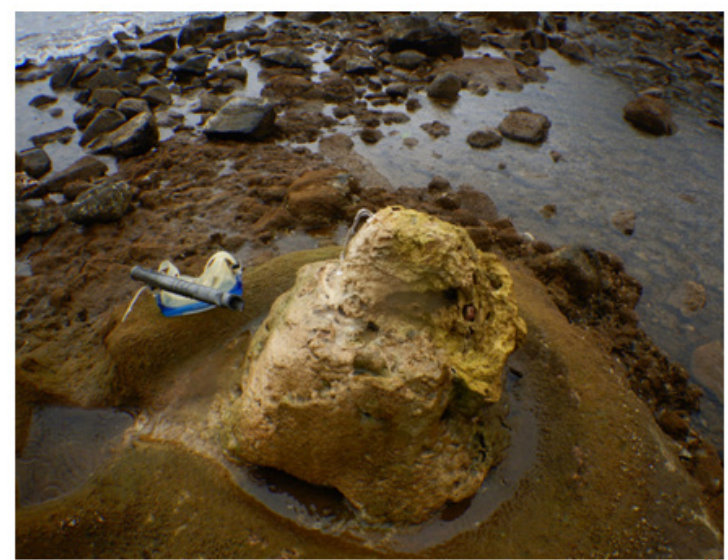

Figure 15: Below the high tide line, the observed submarine groundwater (SGD) spring.

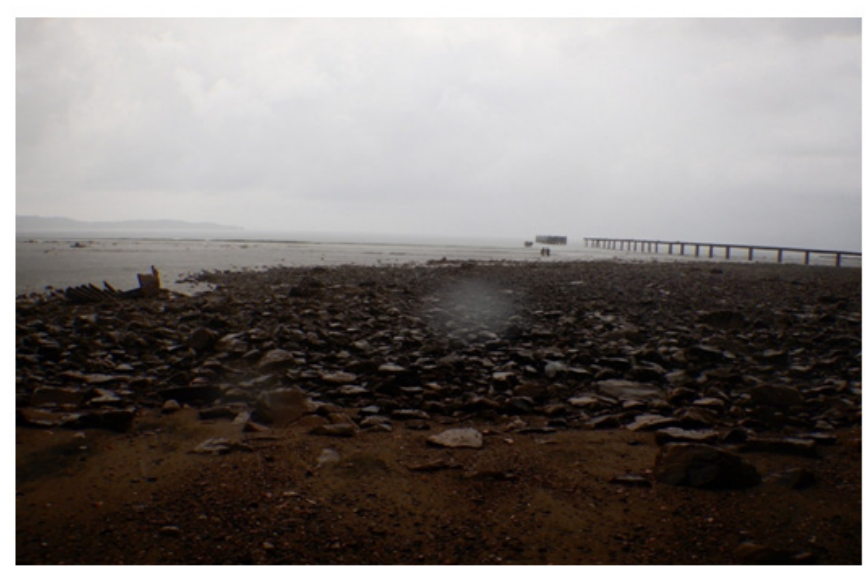

Figure 16: Observed submarine groundwater (SGD) spring location during the Low Tide.

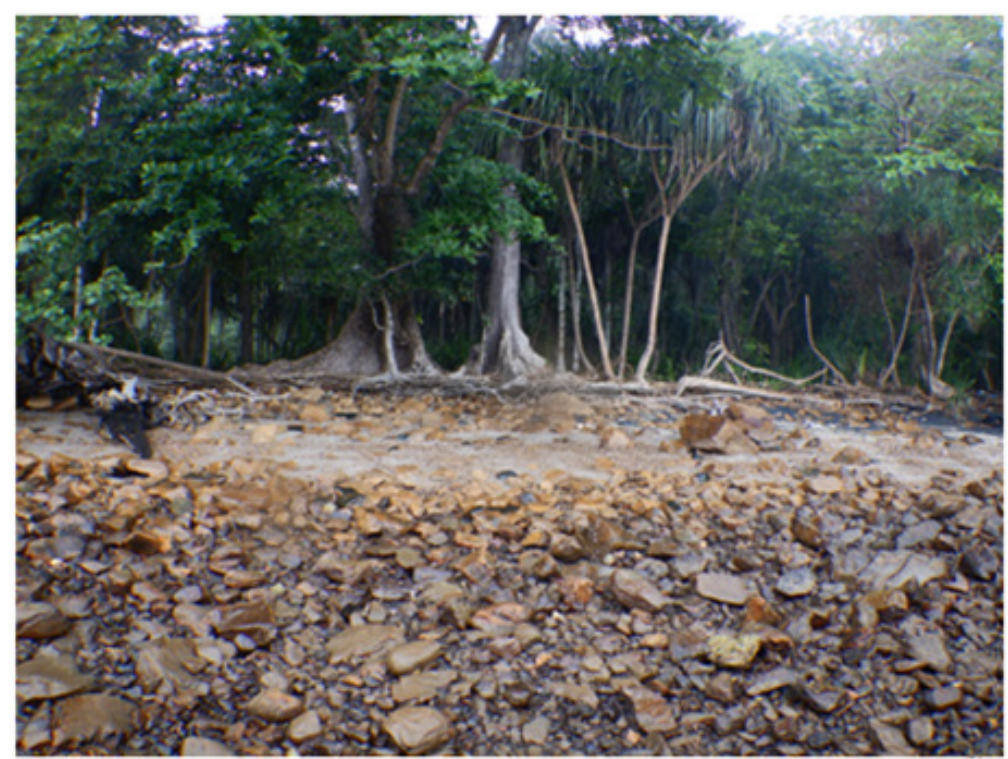

Figure 17: Observed submarine groundwater (SGD) spring location and it Shore. 


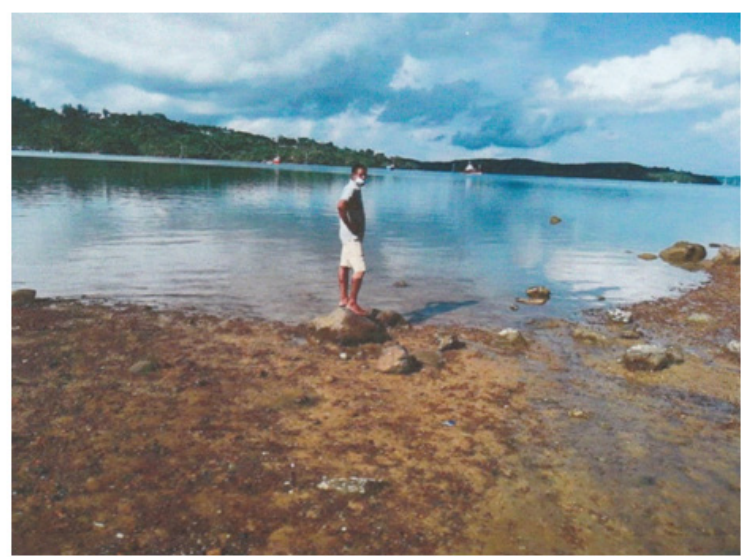

Figure 18: SGD Location at South of Coast Guard Jetty - Low tide level and freshwater flow.

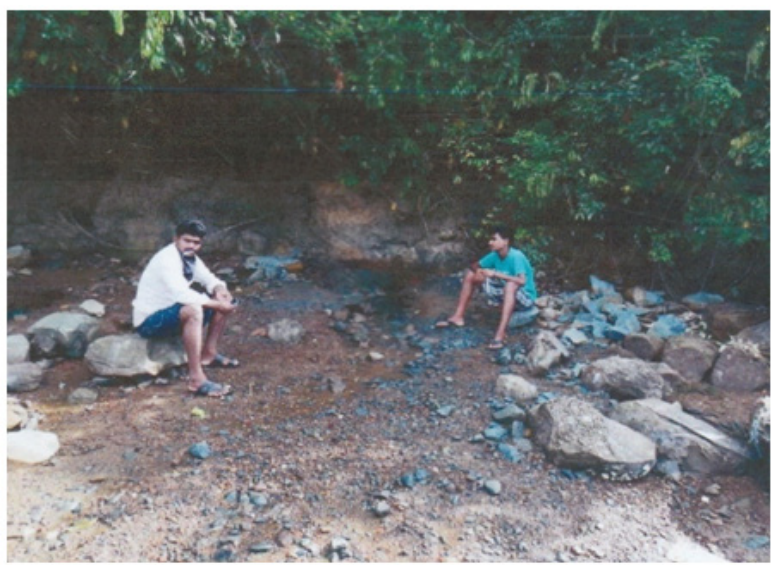

Figure 19: The SGD below the high tide line in the South of Coast Guard Jetty - Junglighat.

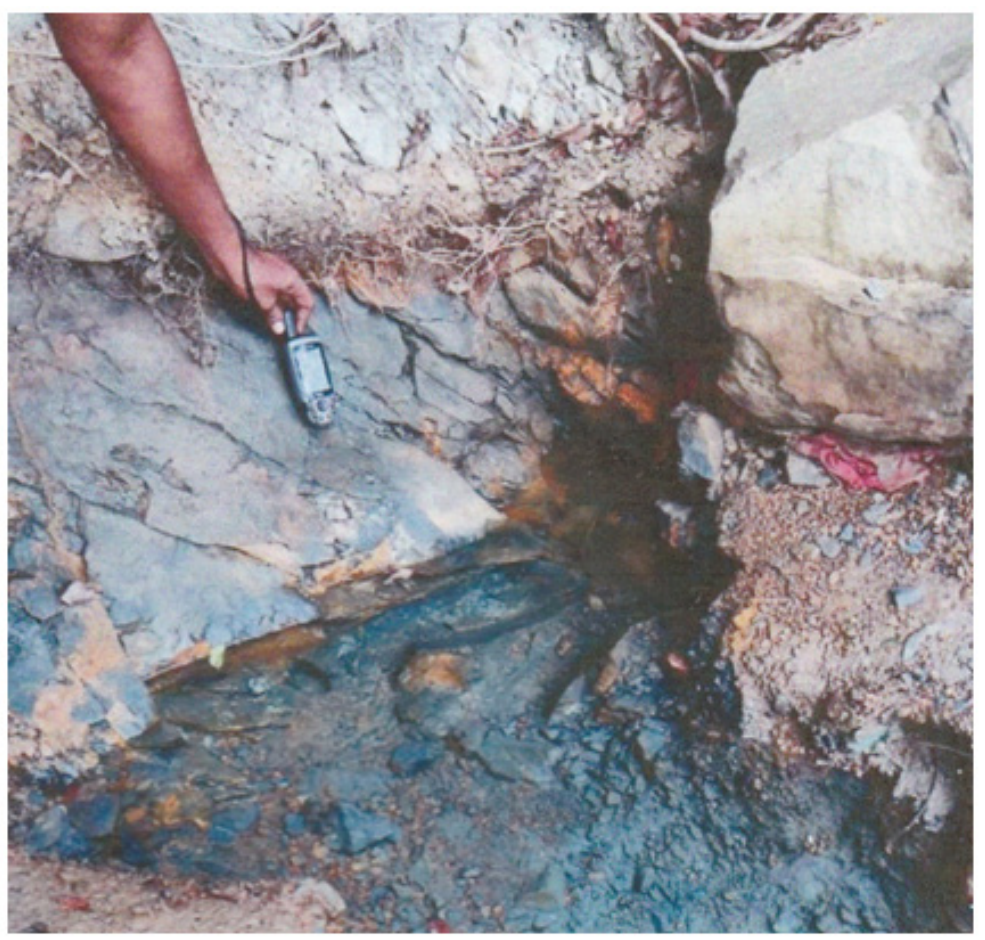

Figure 20: The SGD flow observed between mudstone contact at South of Coast Guard Jetty. 


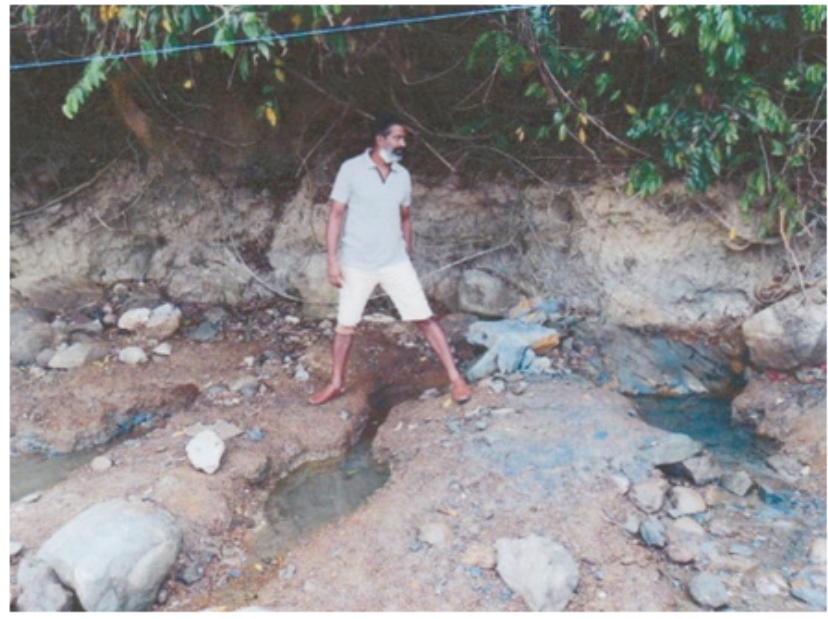

Figure 21: The SGD flow observed in different locations of the mudstone contacts - Junglighat.

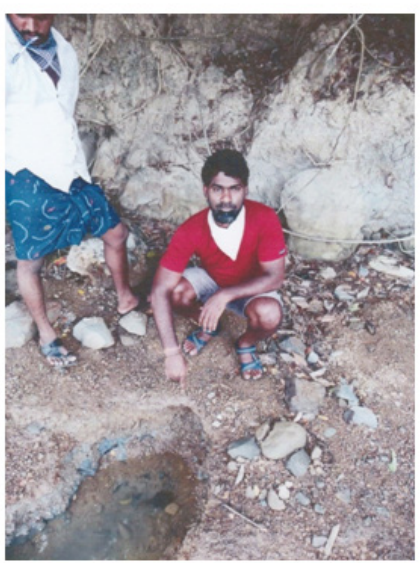

Figure 22: The SGD below the MSL, under the loose sediments during low tide level - Junglighat.

\section{Conclusion}

Overall understanding of the nearshore environment of this Island, based on the studied environmental parameters, suggested that over and above the natural oceanographic processes, the unidentified process also has an effect in this environment. The author's perception is that it may be SGD, which has been evinced by identification two SGD sources along these coastlines, within short distance. So, a serious effort is essential to understand and revalidate the nearshore marine process by a joint venture of oceanographers and hydrologist, which provide a new vista for nearshore marine science environment concepts.

\section{Acknowledgment}

The Authors thank the National Centre for Earth Science Studies (NCESS), Ministry of Earth Sciences, Thiruvananthapuram for the funding this study (NCESS/MOES/ 402/ GIA/2019, dt:29.03.2019). The Authors also thank the Authorities of Pondicherry University, Puducherry for the facility extended to this study.

\section{Conflict of Interest}

No conflict of interest.

\section{References}

1. Church TM (1996) An underground route for the water cycle. Nature 380: 579- 580 .

2. Moore WS (1996) Large groundwater inputs to coastal waters revealed by 226Ra enrichments. Nature 380: 612- 614

3. Kay AE, Lau LS, Stroup ED, Doller SJ, Fellows DP, et al. (1977) Hydrological and ecological inventories of the coastal waters of West Hawaii. University of Hawaii Water Resource Research Center Technical Report 105: 94.

4. Hanshaw BB, Back W (1980) Chemical mass-wasting of the northern Yucatan Peninsula by groundwater dissolution. Geology 8: 222-224.

5. Kim G, Lee KK, Park KS, Hwang DW, Yang HS (2003) Large submarine groundwater discharge (SGD) from a volcanic island. Geophysical Research Letters 30: 2098.

6. Kumari RK, Mohan PM, Dhivya P, Nagarjuna P (2015) Dissolved organic (DOC) and Inorganic carbon (DIC) in the adjacent waters of coral reef environment of Andaman and Nicobar Islands. International Journal of Oceanography and Marine Biology 2: 62-76.

7. Mohan PM, Kumari RK, Muruganantham M, Ubare VV, Jeeva C, et al. (2016) An Experimental Study on the Carbon Flux within the Coral Community. British Journal of Environment \& Climate Change 6: 28-42.

8. Mohan PM, Kumari RK, Muruganantham M, Ubare VV, Jeeva C, et al. (2016) Dissolved Organic (DOC) And Inorganic Carbon (DIC) And Its Distribution In The Nearshore Waters Off Port Blair, Andaman Islands, India. International Journal of Oceans and Oceanography 10: 29-48. 
9. Mohan PM, Kumari RK (2016) Near shore environmental factors and its impact on the seawater. In: Dam Roy et al. (eds.) Proceedings of International Conference on climatic change adaptation and biodiversity: Ecological sustainability and resource management in livelihood security (ASA, ICCB-2016). Andaman Science Association, Port Blair pp.364-373.

10. Kumari RK, Mohan PM (2018) Changes of temperature, $\mathrm{pH}$ and salinity of nearshore waters. Global Journal of Science Frontier Research (E) Marine Science 18: 6-39.

11. Mohan PM, Muruganantham M, Ubare VV (2017) Coral bleaching is a tool for earthquake prediction. ARPN Journal of Earth Sciences 6: 18-25.

12. Kumari RK (2018) Distribution of Dissolved and Particulate Organic Carbon in the nearshore waters of Andaman Islands. An Unpublished PhD Thesis Pondicherry University Puducherry India.

13. Johannes RE, Hearn C (1985) The effect of submarine groundwate discharge on nutrient and salinity regimes in a coastal lagoon off Perth, Western Australia. Estuarine Coastal and Shelf Sciences 21: 789-800.

14. Lapointe BE, O'Connell J (1989) Nutrient-enhanced growth of Cladophora prolifera in Harrington Sound, Bermuda: eutrophication of a confined, phosphorus-limited marine ecosystem. Estuarine Coastal and Shelf Sciences 28: 347-360.

15. Slomp CP, Van Cappellen P (2004) Nutrient inputs to the coastal ocean through submarine groundwater discharge: controls and potential impact. Journal of Hydrology 295: 64-86.

16. Luo X, Jiao JJ, Liu Y, Zhang X, Liang W, et al. (2018) Evaluation of water residence time, submarine ground water discharge, and maximum new production supported by groundwater borne nutrients in a coastal upwelling shelf system. Journal of Geophysical Research in Ocean 123 631-655.

17. Burnett WC, Bokuniewicz H, Huettel M, Moore WS, Taniguchi M (2003) Ground water and pore water inputs to the coastal zone. Biogeochemistry 66: 3-33.

18. Moore WS (2010) The effect of submarine ground water discharge on the ocean. Annual Review on Marine Sciences 2: 59-88.

19. Moosdorf N, Stieglitz T, Waska H, Dürr HH, Hartmann J (2015) Submarine ground water discharge from tropical islands: a review. Groundwater Research 20: 53-67.
20. Taniguchi M, Burnett WC, Cable JE, Turner JV (2002) Investigation of submarine ground water discharge. Hydrological Process 16: 21152129.

21. Dale RK, Miller DC (2008) Hydrologic interactions of infaunal polychaetes and intertidal groundwater discharge. Marine Ecological Progress Series 363: 205-215

22. Waska H, Kim G (2011) Submarine groundwater discharge (SGD) as a main nutrient source for benthic and water-column primary production in a large intertidal environment of the Yellow Sea. Journal of Sea Research 65:103-113.

23. Encarnação J, Leitão F, Range P, Piló D, Chícharo MA, et al. (2014) Local and temporal variations in near-shore macrobenthic communities associated with submarine groundwater discharges. Marine Ecology 36: 926-941.

24. Hata M, Sugimoto R, Hori M, Tomiyama T, Shoji J (2016) Occurrence, distribution and prey items of juvenile marbled sole Pseudopleuronectes yokohamae around a submarine groundwater seepage on a tidal flat in southwestern Japan. Journal of Sea Research 111: 47-53.

25. Amato DW, Bishop JM, Glenn CR, Dulai H, Smith CM (2016) Impact of submarine groundwater discharge on marine water quality and reef biota of Maui. 11(11): e0165825.

26. Utsunomiya T, Hata M, Sugimoto R, Honda H, Kobayashi S, et al. (2017) Higher species richness and abundance of fish and benthic invertebrates around submarine ground water discharge in Obama Bay, Japan. Journal of Hydrology Regional Studies 11: 139-146.

27. Lecher AL, Mackey KRM (2018) Synthesizing the effects of submarine groundwater discharge on marine biota. Hydrobiologia 5: 60 .

28. Piló D, Barbosa AB, Teodósio MA, Encarnação J, Leitão F, et al. (2018) Are submarine ground water discharges affecting the structure and physiological status of rocky intertidal communities. Marine Environmental Research 136:158-173.

29. Foley L (2018) Karst-channelled intertidal submarine groundwater discharge (SGD) conditions the form of the rock pool sessile assemblage. Estuarine Coastal and Shelf Sciences 213: 236-244.

30. Lilkendey J, Pisternick T, Neumann SI, Dumur Neelayya D, Bröhl S, et al. (2019) Fresh Submarine Groundwater Discharge Augments Growth in a Reef Fish. Fronter Marine Science 6-613: 1-11. 